\title{
Impact of Brand Equity on Consumer's Purchase Decision of Smart Phone-A Study on University Students in Chittagong, Bangladesh
}

By Syed Md Hasib Ahsan, Md Kazi Golam Azam, Md. Zohir Raihan, Ishtiak Bin Imam \& Md. Nurul Islam

International Islamic University

Abstract- This study aims to measure the impact of brand equity on customer satisfaction on the Smartphone in Chittagong, Bangladesh. While conducting this study, the research adopted a model questionnaire for the purpose of doing a survey. In this study 300 respondents have been surveyed, where respondents are the university's student of Chittagong. This study examined the brand equity dimensions developed by David Aaker. A number of statistical tools such as correlation and regression analysis have been applied to analyze the collected data from the survey. Statistical software SPSS (version- 22) has been used to make this analysis. The findings of the study reflect that the brand equity dimension such as brand awareness, brand association, perceived quality, brand loyalty have a significant impact on the consumers purchase decisions.

Keywords: brand equity, awareness, brand association, perceived quality, brand loyalty.

GJMBR-A Classification: JEL Code: L68

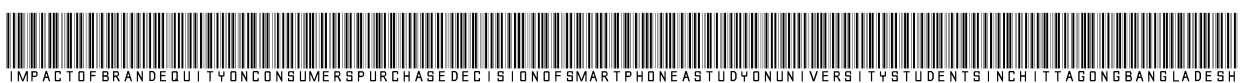

Strictly as per the compliance and regulations of:

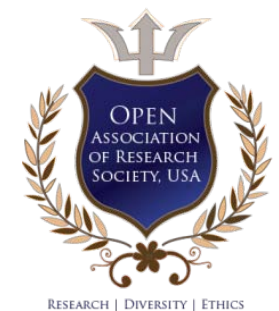

(c) 2020. Syed Md Hasib Ahsan, Md Kazi Golam Azam, Md. Zohir Raihan, Ishtiak Bin Imam \& Md. Nurul Islam. This is a research/review paper, distributed under the terms of the Creative Commons Attribution-Noncommercial 3.0 Unported License http://creativecommons.org/licenses/by-nc/3.0/), permitting all non-commercial use, distribution, and reproduction in any medium, provided the original work is properly cited. 


\title{
Impact of Brand Equity on Consumer's Purchase Decision of Smart Phone-A Study on University Students in Chittagong, Bangladesh
}

\author{
Syed Md Hasib Ahsan ${ }^{\alpha}$, Md Kazi Golam Azam ${ }^{\circ}$, Md. Zohir Raihan ${ }^{\rho}$, Ishtiak Bin Imam ${ }^{\omega}$ \& Md. Nurul Islam ${ }^{*}$
}

\begin{abstract}
This study aims to measure the impact of brand equity on customer satisfaction on the Smartphone in Chittagong, Bangladesh. While conducting this study, the research adopted a model questionnaire for the purpose of doing a survey. In this study 300 respondents have been surveyed, where respondents are the university's student of Chittagong. This study examined the brand equity dimensions developed by David Aaker. A number of statistical tools such as correlation and regression analysis have been applied to analyze the collected data from the survey. Statistical software SPSS (version- 22) has been used to make this analysis. The findings of the study reflect that the brand equity dimension such as brand awareness, brand association, perceived quality, brand loyalty have a significant impact on the consumers purchase decisions.
\end{abstract}

Keywords: brand equity, awareness, brand association, perceived quality, brand loyalty.

\section{INTRODUCTION}

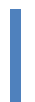
$\mathrm{n}$ the modern era, consumer awareness has increased, which has led them to make a decision to buy a familiar and profitable brand. Hence, in order to compete effectively, businesses have to do more to ensure that consumers buy more of their products and brands. Because brands have the unique attributes of contributing to firms' assets, brands are often considered as vital ingredients that add considerable value to the organizations. As a result, many organizations are searching for the vast scope to sustain present brands rather than expanding new brands. Moreover, the brand manager's tactical tool is brand equity, which assists in exploiting economic indications as well as marketing efficiency (Yoo and Donthu, 2001). It is commonly thought that the brand enhances the long-term profitability of a company. However, brand equity's concept has grown rapidly over the past few decades. Proper management of brand equity leads "consumer loyalty, low risk of marketing activity and crisis, flexible response to price fluctuations, more

Author a $\sigma$ : Assistant Professor Department of Business Administration International Islamic University Chittagong.

e-mails: hasib27.ahsan@gmail.com,mdkgazam@gmail.com

Author $\rho \omega ¥$ : Department of Business Administration International Islamic University Chittagong. e-mails: zohirraihan1861@gmail.com, istiak519@gmail.com,nirob5411@gmail.com business support and cooperation, effectiveness of marketing communications, licensing opportunities, additional opportunities for brand extension, more attraction for investors, and support from investors (Aaker, 1991; Keller, 2003; Van Auken, 2005), greater profit margins (Kim and Kim, 2005), ability to attract good employees (DelVecchio, et al. 2007), protection of potential competitors entrance during outsourcing" (Tan and Lim, 2009). Different brand equity models have found nowadays, whereas we had chosen a model which is developed by David Aaker (1991). Brand equity is an eminent model for brand research over the period. Previous researches were focused on different contexts of the brand model where they used Aaker's (1991) model, for instance, hostelling and airlines, but no one had done any research on "the impact of brand equity on consumer's Smartphone purchase decision in Chittagong". In an attempt, we try to find out the relationship between the purchases decisions of consumers and dimensions. The researchers of the brand have developed numerous concepts of brands and the way how brands effect on customers present and future's purchasing behavior. The Smartphone industry in Bangladesh is one of the best rising sectors with high export potential. This study examines the relationship between the brand value of a Smartphone manufacturer and the purchase decisions for potential customers.

\section{Literature ReVieW}

The term brand has been using for many years; the brand value is a core concept for raising institutions that have emerged in the last twenty years (Leone et al, 2006). Buying decision is a kind of decision in which we examined that why a consumer purchases a particular brand. Sproles and Kendall (1986) mentioned that "a purchaser's decision-making style is a mental orientation characterizing a consumer's approach to making choices". Furthermore, cognitive and perceptual models assume that the knowledge of brand affects customer response to the brand. According to Schiffman and Kanuk (2000), "customer behavior is how consumers take a decision for household or personal goods by using their resources such as money, effort and time". Several models are developed to depict the customer 
purchasing attitudes. The process of the Customer decision model has 7 stages in which customers need to go through those 7 stages before entering their ultimate decisions. In addition, all stages are following; "need recognition, search for information, pre-purchase, evaluation, purchase, consumption, post-consumption evaluation and divestment" (Blackwell et al., 2006). Stage one is "need recognition". The purchasing process begins when consumers recognize their unsatisfactory needs (Levy and Weitz, 1995). However, the classification of needs is two, the first one is "functional needs" and the second one is "psychological needs". On the one hand, functional needs which are involved in the product's performance. On the other hand, the needs of psychological are acquired when consumers feel satisfied with owning a product or goods. The second stage is the "search of information". The depth of search is varied for different consumers and it depends on some variables, for instance, income, personality, and consumer satisfaction (Moorthyet et al., 1997). Also, the search for information can be classified into two ways, (1) "prepurchase search" (2) "ongoing search", mentioned by Solomon et al. (2006). However, Pre-purchase research begins when buyers identify the need and then they are looking for more market information. And, ongoing research is likely to be based on the self-interest of a specific brand. The third stage is "pre-purchase assessment", whereas the customer makes a comparison with different services and brands for making a purchase decision. Moreover, customers give attention to the attributes of products that are relevant to their needs and it is also included in this stage (Kotler et al., 2005). To judge a brand, customers are using the following attributes, quality, price, and quantity. Blackwell et al., (2006) mentioned that the changes in attributes can affect the customer's decision and the product or brand of the choices. However, Porter (2004) mentioned that Smartphone industries can increase their competitive advantages by creating some values. The fourth stage is "Purchase decision" which comes after considering various retail offerings. In the fifth stage, consumers are started purchasing the products or goods, whereas consumers evaluate the purchasing process in the sixth stage. In the seventh stage, customers recycle or dispose of the products.

\section{a) "Brand Equity"}

Brand equity is the commercial value that comes from customer perception of the brand name of a particular product or service. Aaker (1991) mentioned that "brand equity as an aggregate variable of the five dimensions of the brand assets, for instance, brand loyalty, perceived quality, brand awareness, brand association, and other proprietary assets". However, brand equity's positive side is that it happens when customers are intending to give more for the same level of quality only because of the attractiveness of the brand name attached to the product mentioned by Bello and Holbrook (1995). Nevertheless, if brand equity is not managed properly then it will be destroyed. For instance, poor services and poor product quality may affect the image of the brand.

\section{b) "Brand Awareness"}

Brand awareness is a marketing term that depicts the degree of customer recognition of a product by its name. Aaker (1996) mentioned that brand awareness is a consumer's ability to identify a brand by its product or service category. A small number of customers make their purchase decisions by the brand's goodwill in the market (Keller, 1993). Keller (2003) mentioned that brand awareness plays an important role in customer decision making by bringing some advantages; these are the following, consideration advantages, learning advantages and choice advantages. Therefore, we may anticipate that

H1: "Brand awareness might have a positive impact on customer's purchase decision".

\section{c) "Brand Association"}

Brand associations are brand attributes that come to mind when consumers talk about a brand. "Brand associations contribute to brand equity by making a non-attribute-based component of brand equity and an attribute-based component of brand equity and provide evidence by supporting their conceptualization" (Park and Srinivasan, 1994). However, a brand association is "anything linked in memory to a brand" (Aaker, 1991). Aaker (1991) mentioned that the benefits of brand associations are the following: differentiating the brand, creating positive feelings, generating a reason to purchase and providing a basis for extensions. From the above literature we can hypothesize that:

H2: "Brand association might have a positive impact on customer's purchase decision".

\section{d) "Perceived Quality"}

"Perceived quality of a brand could help to generate values by charging a premium price, providing a pivotal reason-to-buy, differentiating the position of a brand, motivating channel members to perform well and also introducing extensions into new brand groups", mentioned by Aaker (1991). Furthermore, price is one of the significant clues to examine the perceived quality, (Aaker, 1991). Thus it is hypothesized from the above literature that:

H3: "Perceived quality might have a positive impact on customer's purchase decision".

e) "Brand loyalty"

Brand loyalty is "a deeply held commitment to re-buy or re-patronize a preferred product or service 
consistently in the future, despite situational influences and marketing efforts having the potential to cause switching behavior" (Oliver 1997). It shows the motivation to be loyal towards the brand, and it is reflected when consumers choose the brand as their first choice mentioned by Yoo \& Donthu (2001). Customers continue to buy the brand because of the loyalty of a brand, regardless of the convenience and prices which are owned by its competitors (Aaker, 1991). Thus it is hypothesized from the above literature that:
H4: "Brand loyalty might have a positive impact on customer's purchase decision".

\section{ili. Conceptual Framework}

With an objective to find the nexus between Brand Equity and Consumer's Purchase intention a theoretical framework has been formed where consumers' purchase decisions is associated with brand awareness, brand associations, perceive quality and brand loyalty

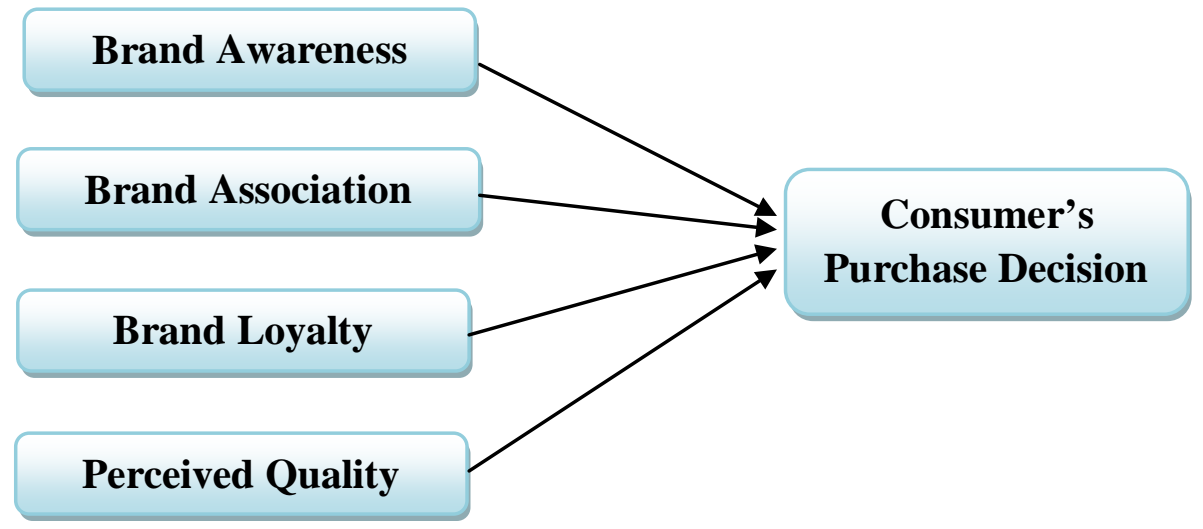

\section{Research Objectives} objectives:

This study is designed with the following

- This study has been designed with an objective to evaluate the impact of Brand Equity dimensions of David Aaker Brand Equity model on customer's buying decision of smart phones in Chittagong.

- Also, this study designed to understand different dimension of Brand Equity model developed by David Aaker

\section{Methodology}

The objective of this research is to measure the impact of brand equity on customers buying decisions.
In this study, the impact of brand equity dimensions on customers buying decisions is measured. It is quantitative research. A questionnaire is adopted to conduct a survey, whereas the respondents were 300 who were living in Chittagong. A convenience sampling method has been used to select the samples. Tools and techniques used in analyzing the collected data and information were mostly statistical in nature. Statistical Techniques such as reliability analysis and regression analysis were done with the help of SPSS-22 software.

Table 1: Test of Reliability"

Reliability Statistics

\begin{tabular}{|c|c|}
\hline Cronbach's Alpha & N of Items \\
\hline .870 & 22 \\
\hline
\end{tabular}

a) Data Analysis

Table 2: Shows Correlations"

Correlations

\begin{tabular}{|cl|c|c|c|c|c|}
\hline & $\begin{array}{c}\text { Brand } \\
\text { Awareness }\end{array}$ & $\begin{array}{c}\text { Brand } \\
\text { Association }\end{array}$ & $\begin{array}{c}\text { Brand } \\
\text { loyalty }\end{array}$ & $\begin{array}{c}\text { Perceived } \\
\text { Quality }\end{array}$ & $\begin{array}{c}\text { Purchase } \\
\text { Decision }\end{array}$ \\
\hline \multirow{2}{*}{ BAW } & 1 & $.717^{* *}$ & $.781^{* *}$ & $.884^{* *}$ & $.905^{* *}$ \\
& Pearson Correlation & & .000 & .000 & .000 & .000 \\
& Sig. (2-tailed) & 300 & 300 & 300 & 300 & 300 \\
\hline \multirow{2}{*}{ BAS } & Pearson Correlation & $.717^{* *}$ & 1 & $.627^{* *}$ & $.817^{* *}$ & $.857^{* *}$ \\
& Sig. (2-tailed) & .000 & & .000 & .000 & .000 \\
\hline & N & 300 & 300 & 300 & 300 & 300 \\
\hline \multirow{2}{*}{ BLO } & Pearson Correlation & $.781^{* *}$ & $.627^{* *}$ & 1 & $.807^{* *}$ & $.839^{* *}$ \\
& Sig. (2-tailed) & .000 & .000 & & .000 & .000 \\
& N & 300 & 300 & 300 & 300 & 300 \\
\hline \multirow{2}{*}{ PQU } & Pearson Correlation & $.884^{* *}$ & $.817^{* *}$ & $.807^{* *}$ & 1 & $.926^{* *}$ \\
& Sig. (2-tailed) & .000 & .000 & .000 & & .000 \\
& $N$ & 300 & 300 & 300 & 300 & 300 \\
\hline
\end{tabular}




\begin{tabular}{|ll|c|c|c|c|c|}
\hline \multirow{3}{*}{$\mathrm{CPD}$} & Pearson Correlation & $.905^{* *}$ & $.857^{* *}$ & $.839^{* *}$ & $.926^{* *}$ & 1 \\
& Sig. (2-tailed) & .000 & .000 & .000 & .000 & \\
& $\mathrm{~N}$ & 300 & 300 & 300 & 300 & 300 \\
\hline
\end{tabular}

**. Correlation is significant at the 0.01 level (2-tailed).

Table 2 shows the correlation among the variables (both dependent and independent variables). The results show positive and very significant correlations among the variables. The strongest correlation is found in between 'Product Quality' and
'Purchase Decision' which is .926. The value .905 also indicates stronger correlation between 'Brand Awareness' and 'Purchase Decision'. The correlation matrix table shows that all the variables are strongly correlated with each other.

Table 3: Shows Case Processing Summary

Model Summary

\begin{tabular}{|c|c|c|c|c|}
\hline Model & $\mathrm{R}$ & $\mathrm{R}$ Square & $\begin{array}{c}\text { Adjusted R } \\
\text { Square }\end{array}$ & $\begin{array}{c}\text { Std. Error of the } \\
\text { Estimate }\end{array}$ \\
\hline 1 & $.970^{\mathrm{a}}$ & .940 & .940 & .09192 \\
\hline
\end{tabular}

a. Predictors: (Constant), PQU, BLO, BAS, BAW

Table 4: Shows ANOVAa"

ANOVA $^{a}$

\begin{tabular}{|c|c|c|c|c|c|}
\hline Model & Sum of Squares & $\mathrm{Df}$ & Mean Square & $\mathrm{F}$ & Sig. \\
\hline $\begin{array}{cc} & \text { Regression } \\
1 & \text { Residual } \\
& \text { Total }\end{array}$ & $\begin{array}{c}39.322 \\
2.492 \\
41.815\end{array}$ & $\begin{array}{c}4 \\
295 \\
299\end{array}$ & $\begin{array}{c}9.831 \\
.008\end{array}$ & 1163.507 & $.000^{b}$ \\
\hline
\end{tabular}

a. Dependent Variable: $C P D$

b. Predictors: (Constant), PQU, BLO, BAS, BAW

The ANOVA table shows the $R$ square value is .940 which is highly impressive. It means 94\% of variance in 'Purchase Decision' is explained by the

predictors (independent variables). And adjusted $\mathrm{R}$ square is also .940 .

Table 5: Shows Coefficients ${ }^{a^{\prime \prime}}$

Coefficients $^{a}$

\begin{tabular}{|c|c|c|c|c|c|c|}
\hline & \multirow{2}{*}{ Model } & \multicolumn{2}{|c|}{ Unstandardized Coefficients } & $\begin{array}{c}\text { Standardized } \\
\text { Coefficients }\end{array}$ & \multirow{2}{*}{$t$} & \multirow{2}{*}{ Sig } \\
\hline & & $B$ & Std. Error & Beta & & \\
\hline \multirow{5}{*}{1} & (Constant) & .116 & .059 & & 1.968 & .050 \\
\hline & BAW & .361 & .034 & .330 & 10.537 & .000 \\
\hline & BAS & .348 & .026 & .329 & 13.317 & .000 \\
\hline & BLO & .158 & .017 & .230 & 9.245 & .000 \\
\hline & PQU & .179 & .040 & .179 & 4.514 & .000 \\
\hline
\end{tabular}

a. Dependent Variable: $C P D$

From table-5, the b coefficients tell us how many units dependent variable change for a single unit change in each predictor. Like so, 1 unit increase in 'Brand Awareness' corresponds to .361 unit increase in "Purchase Decision" and so on. Here all b-coefficients are positive numbers that explain positive correlation between dependent variable (Purchase Decision) and independent variables (Brand Awareness, Brand Association, Brand Loyalty and Purchase Quality). Therefore, as significant and positive correlations exist among the variables all alternate hypothesis such as $H 1$, $\mathrm{H}_{2}, \mathrm{H} 3$ and $\mathrm{H} 4$ are accepted.

\section{Conclusion}

This study sets out to measure the brand equity impact on customer's purchase decisions on smart phone. The results of this investigation show that the customer's purchase decision is significantly influenced by brand equity dimensions. In a developing country like Bangladesh, consumers usually prefer the products that are inexpensive and mostly non-branded. However, the findings of this study suggest that the consumers in Chittagong consider brand awareness, brand association, perceived quality, and brand loyalty very 
important while making their purchase decisions and that is why good brands have emerged locally to serve the smart phone markets with their high brand equity.

\section{References Références Referencias}

1. Del Vecchio, Devon, Cheryl B. Jarvis, Richard R. Klink and Brian R. Dineen (2007), "Leveraging Brand Equity to Attract Human Capital," Marketing Letters, 18 (April), 149- 164.

2. Lim W. S. and Tan S. J. (2009). Using brand equity to counter outsourcing opportunism: A game theoretic approach. Marketing Letter. 20:369-383

3. Kim, H. and Kim, W. G. (2005), "The relationship between brand equity and firms' performance in luxury hotels and restaurants", Tourism Management, Vol. 26, pp. 549-60

4. Leone RP, Rao VR, Keller KL, Luo AM, McAlister L, Srivastava $R$ (2006) Linking brand equity to customer equity, Journal of Service Research, 9(2):125-138.

5. Sproles GB, Kendall EL (1986) A methodology for profiling consumers' decision-making styles, J. Consum. Aff, 20(2):267-279.

6. Schiffman LG, Kanuk LL (2000) Consumer Behavior, Pearson Prentice Hall, Englewood Cliffs, New York.

7. Blackwell RD, Miniard PW, Engel FJ (2006) Consumer Behaviour. Mason: Thomson

8. Levy, M., Weitz, B. A. (1995). Retailing management (2nd ed.). Burr Ridge, IL: McGraw-Hill/Irwin.

9. Moorthy, S., Ratchford, B.T. and Talukdar, D. (1997) , "Consumer information search revisited: theory and empirical analysis", Journal of Consumer Research, Vol. 23 No. 4, pp. 263-77.

10. Solomon M., Bamossy G., Askegaard S., Hogg M.K. (2006) Consumer Behaviour. A European perspective, 3rd ed. Prentice Hall Financial Times.

11. Kotler, P., Wong, V., Saunders, J., Armstrong, G. (2005), Principles of Marketing. Essex: Pearson Education Limited.

12. Porter, M. E. (2004), Competitive Strategy: Techniques for Analyzing Industries and Competitors. London: Free Press

13. Bello, D. C. and Holbrook, M. B. (1995), "Does an absence of brand equity generalize across product classes?", Journal of Business Research, Vol. 34 No. 2, pp. 125-31

14. Keller, K. L. (2003), Strategic Brand Management, 2nd ed., Prentice Hall, Upper Saddle River, NJ.

15. Aaker, D. A. (1996) Measuring brand equity across products and markets. California Management Rev. 38 (Spring): 102-120.

16. Van Auken, B., 2005, The brand management checklist: proven tools and techniques for creating winning brands, Kogan-Page Pub, London, UK

17. Park, C. S. and Srinivasan, V. (1994), "A surveybased method for measuring and understanding brand equity and its extendibility", Journal of Marketing Research, 31 (5): 271-88.

18. Oliver, R. L., Satisfaction: A Behavioral Perspective on the Consumer, New York, McGraw Hill, 1997.

19. Yoo, B., \& Donthu, N. (2001). Developing and validating multidimensional consumer - based brand equity scale. Journal of Business Research, 52, 1-14.

20. Aaker D (1991) Measuring Brand Equity across Products and Markets, California Management Review 38 (spring), New York: Free Press. 1996,102-120

21. Blackwell, R. D., Miniard, P. W., Engel, F. J. (2006), Consumer Behaviour. Mason: Thomson. 